\title{
Eating disorders among men in the context of mental health and socio-cultural gender issues
}

PRZEGLĄD KRYTYCZNY

2021 / 3(1): 65-78

ISSN: $2657-8964$

DOI: $10.14746 /$ pk.2021.3.1.4

\author{
Dorota Mroczkowska $^{1}$ 앙 \& Beata Ziółkowska ${ }^{2}$ \\ ${ }^{1}$ Adam Mickiewicz University in Poznan, Faculty of Sociology, Szamarzewskiego 89 C, 60-568 Poznań, Poland. ORCID: \\ 0000-0003-4410-0276,Email: drmrocz@amu.edu.pl \\ ${ }^{2}$ Kazimierz Wielki University, Departmet of Pychology, ul. Powstańców Warszawy 1a/6, 85-681 Bydgoszcz, Poland. ORCID: \\ 0000-0002-9864-4634,Email: beataz@ukw.edu.pl
}

ABSTRACT: The paper undertakes the issues of epidemiology, conditions, and treatment of eating disorders in men, which are not widely recognised both in Polish and international research. The text is based on desk research analysis of research reports on eating disorders. Authors discuss the issue of eating disorders in the context of gender, indicating that the clinical picture of them (including the perception of one's own body, the ways and motives for striving for a perfect figure) is mainly related to the stereotypical roles and tasks that society and culture impose on men and women. The empirical material analysis allows us to assume that ED symptoms in men are more often (than in the case of women) related to (self) stigmatisation, diagnosis difficulty, coexistent dimorphic disorders, substance addictions, and more significant physical activity.

KEYWORDS: eating disorders in men, gender, culture, (self) stigmatisation, sexual orientation, physical activity

\section{INTRODUCTION}

$\mathrm{O}$ ne in ten people with eating disorders is a man or a boy. An even higher percentage of this population has problems with compulsive exercise. Increasingly younger men and teenage boys experience dissatisfaction with their image and undergo corrective treatments. These problems are also highly visible in appearance and attitude towards the body, including body image disorders, muscle dysmorphia and the use of anabolic steroids (Pope et al. 2000b).

The problem appears in a broader context recognised by various researchers as the changes in masculinity models generally associated with a significant relativisation of the masculine category, the progressive process of the emancipation of women and the blurring of the distinction between roles played by representatives of both sexes (Morgan et al. 2008). 
In the history of research on eating disorders (ED) the prevailing view is that it is female, which is a crucial risk factor for their development (cf. Streigel-Moore \& Bulik 2007). The insufficient knowledge about ED in the male population is explained by the low morbidity rate, resulting in the exclusion of men from epidemiological studies (Murray et al. 2016; Murray et al. 2017). Despite descriptions of male anorexia cases in as early as the 16th and 17th centuries, they were not included in studies until 1972 (Beaumont et al. 1972). Male patients with anorexia were excluded from most empirical projects meant to develop diagnostic criteria and treatment programmes for eating disorders (Lavender et al. 2017). Murray et al. (2016) report that less than 1\% of studies on anorexia were conducted in the male population. At the same time, it was noted that between 1999 and 2009, the number of men hospitalised for eating disorders and their consequences increased by 53\% (Zhao \& Encinosa 2011).

The text aims to analyse the phenomenon of eating disorders as a form of adverse health behaviours in men in the context of, firstly, the broader perspective of sex and gender relations and secondly, on critical studies on men and masculinities (CSMM). Concerning the first point, we assume that it is not so much a "biological fact" of being a woman or a man that explains the frequency of doctor visits or exhibiting risky health behaviours as a "social fact" indicating how gender is understood and "played out” in a given society (cf. Courtenay 2000; Kluczyńska 2010). In this context, there are many determinants of health behaviour that operate simultaneously. Some of them are universal, while some are related to socio-economic development, healthy and unhealthy lifestyle habits, genetic burden and gender. For example, strength, independence and reliability of the body are inherent in the image of masculinity; thus, men more often than women ignore health problems or postpone visits to doctors, worrying that admitting weakness is a threat to their male identity (Kluczyńska 2010: 189). From the second perspective, which is based on critical studies on men and masculinities (CSMM) (Connell 1995, 2002), different health behaviours of women and men should be analysed in the light of cultural specificity, social expectations, and individuals choices shaping their identity.

This paper is based on the data collected during the desk research procedure (Bednarowska 2015; Babbie 2012). It was assumed that desk research should be a planned and structured search for information on a well-defined topic, modified or narrowed down as knowledge is acquired. The desk research analysis aimed at searching for information, its selection, synthesis, and critical interpretation. The data gathered in such a way allows us to identify and analyse the problem of EDs both in a broad context and from a chosen aspect (e.g. specificity of eating disorders in men).

The analysis proceeded in the following stages:

Firstly, the selection of research material. Forty texts of databased such as Google Scholar, Scirus, Scopus, PubMed, PsycArticles, due to the availability of scientific and academic articles in psychology, medicine and sociology. We have selected research articles based on clinical studies or reports from studies carried out in academic institutions and clinics in Europe and North America. The studies concerned women and men aged between 14 and 40. The research reports conducted in the last decade were taken into consideration. However, the authors used the older ones because of their 
analytical usefulness.

Secondly, repeated reading of texts which have been included in the sample because of the following research purposes: exploring the nature of eating disorder in men, determining the frequencies of EDs in men and presenting the diagnosis of EDs in men

Thirdly, the creation of a critical category and the definition of categories in the key. The main keywords to be considered are: eating disorders in women and man, eating disorder epidemiology, eating disorder diagnosis, gender differences in eating disorder.

Fourthly, the construction of tables with citations.

\section{MEN'S HEALTH IN THE CONTEXT OF SEX AND GENDER DILEMMAS.}

As documented in the studies by Woynarowska (2012), people perceive health in three dimensions. The first one concerns fitness and the ability to perform various activities related to work and leisure. Secondly, undertaking health-promoting behaviours, such as a proper diet, adequate amount of sleep, etc., is a symptom of health. Thirdly, people perceive mental health, defined above all as well-being and satisfying relationships with others, as a significant factor in overall health. With the premise of the bio-psycho-social unity of human performance, we assume that both the health condition and the objectives and areas of health interventions are related to the functioning of an individual in three basic dimensions (Erikson 2002): 1) soma - disease burden, drug burden, physical fitness, nervous system strength, immune resistance, etc.; 2) psyche - self-esteem, self-image, psychological needs - gratification vs frustration, insight into one's strengths and weaknesses, resilience to stress, optimism vs pessimism, behavioural patterns, etc., 3) polis - support network, acceptance vs social isolation, interpersonal bonds, styles of social functioning, participation in positive and negative social groups, experiencing social labelling and exclusion, cooperation vs competition, etc.

It is, therefore, safe to assume that the categories of gender and mental health are dependent on the cultural and social contexts and undergo transformation within them. According to Davidson et al. (2006) and Vlassoff (2007), gender is moreover a moderating variable (not intervening variable) for all health determinants, i.e. biological, psychological and social. Feminist research has illustrated the complex processes by which biological facts are contextually defined and, therefore, gendered (Saetnan et al. 2000).

The relationship between the categories of sex/gender and mental health is confirmed by both international quantitative epidemiological data and qualitative clinical observations. It appears that particular mental disorders are significantly more frequently diagnosed either in women or in men. What is more, there are differences in the clinical outcome of some mental disorders (e.g. depression or addiction) depending on the gender of patients (Renzetti \& Curran 2003). Thus, diseases that clinical picture reflects traditional femininity patterns are significantly more frequently diagnosed in the female population, whereas diseases and disorders resemble patterns 
of masculinity in the male population (WHO 2011). Diseases diagnosed much more frequently in women (Brannon 2017: 466-504; Russo \& Green 2002: 303-343) include depression, anxiety disorders, personality disorders including avoidant, dependent (symbiotic), histrionic, and borderline (unstable) personality, and eating disorders (anorexia and mental bulimia). Among men, on the other hand, more common are addictions to psychoactive substances and such personality disorders as anti-social, narcissistic, schizoid, paranoid and obsessive-compulsive.

Women are also much more likely to suffer from eating disorders such as anorexia or bulimia nervosa than men (Królikowska 2011: 388-389). According to the appearance stereotype, a woman should be small, delicate and light, which corresponds with women's behaviours - they tend to choose such forms of physical activity or diet that will help them achieve the promoted aesthetic ideal. Moreover, while taking care of their appearance, women often exhibit behaviours that may have adverse health effects, such as surgical interventions to improve their figure, excessive use of preparations and cosmetic treatments or excessive sunbathing in solarium. On the other hand, men are willing to meet the male appearance stereotype with an athletic, muscular figure, engage themselves with bodybuilding or other intensive physical exercises, especially strength training. Not uncommon is the use of steroids and other means for a rapid increase in muscle mass or fat tissue loss, which affects their health.

Apart from some apparent differences in health between men and women, it is not always clear which differences in men's and women's health are the result of sex differences (what is inherent) and which are due to gender (which is socially acquired) (Doyal 2001).

CSMM's health research has been sceptical to research that lists the various ways in which men's health is disadvantaged, relative to women's, without considering the complex processes by which health statistics are gendered (Lohan 2007: 494). Connell (1995, 2002; cf. Cinciara 2015: 348-349) points out that masculinity and femininity are not constant and unchangeable, and there co-exist various masculinities and femininities showing similarities and differences. They arise not from social expectations as from everyday practices sanctioned by customs and perceived as natural and socially acceptable. Hierarchically, the most important is the so-called hegemonic masculinity, which for example, in Anglo-Saxon culture is about striving to dominate and subjugate both women and other men. Not all men demonstrate hegemonic masculinity, but almost all of them gain from it, drawing tangible benefits from patriarchy's sustainability. The weakest and dominated by other groups are, e.g. men of different skin colour (marginalised masculinity) or homosexual men (subordinate masculinity). Adopting this theory to analyse health issues, one can assume that hegemonic masculinity can have twofold health effects. The beneficial effect is, for example, related to achieving high socio-economic status, education, profession, income and prestige. On the other hand, the negative impact stems from the price one has to pay for exhibiting hegemonic masculinity, such as an unshakeable belief in one's strength and indestructibility, denial of the disease, undertaking various health risk behaviours, including violence and crime (Mathewson 2009). A key mechanism within CSMM is prioritising a research focus on diversity in how masculinities and health operate in 
daily lives between men and by relating this diversity to the broader social, cultural and economic milieu (O’Brien et al. 2005; Robertson 2007).

\section{EATING DISORDERS IN MEN - INDICATORS AND DETERMINANTS}

Eating disorders (ED) are one of the diseases diagnosed much more frequently in women. Eating disorders are a group of mental problems reflecting traditional stereotypes of femininity. At the turn of the 21 st century, it was estimated that 70 to $95 \%$ of all people diagnosed with anorexia (anorexia nervosa, AN) are women (Józefik 1999: 26). Currently, the incidence of anorexia nervosa (AN) among men is on the rise, and the ratio between women and men has changed from 9:1 to 4:1 over the last 20 years (Keski-Rahkonen et al. 2007). Stice \& Bohon (2012), having analysed and integrated information from various sources, indicated that anorexia in the female population is between $0.9 \%$ and $2.0 \%$, and between $0.1 \%$ and $0.3 \%$ in the male population. According to Mond et al. (2014; cf. Valente et al. 2017), men make up 25\% of all anorexia nervosa cases. Some researchers assess the risk of death from AN and its complications as irrelevant to gender (Smink et al. 2012). Others (Mond et al. 2014) claim that men with AN are at a higher risk of premature death compared to women because, in their case, the disorder is diagnosed much later than in women. Thus, at the moment of diagnosis, the symptoms are more persistent, complications are more severe, and the prognosis is worse; for example, on average, eating disorders are diagnosed between 18 and 26 years of age in men, while among women, it is between 15 and 18 (Krenn 2003).

Epidemiological data on bulimia nervosa $(\mathrm{BN})$ indicates that $1.5 \%$ of women and $0.5 \%$ of men suffer from this disorder (Hudson et al. 2007). On the other hand, Stice and Bohon (2012), analysing the reports of various researchers on the incidence of bulimia and binge eating disorder (BED), show that bulimia occurs in $1.1 \%$ to $4.6 \%$ of women and $0.1 \%$ to $0.5 \%$ of men, and binge eating disorder in up to $3.5 \%$ of the female population and $2 \%$ of the male population. According to Westerberg and Waitz (2013), about $40 \%$ of people with binge eating disorder are men. However, Maine and Bunell (2010) claim that bulimia nervosa is commonly underdiagnosed in men and regarded as a "big appetite", which is considered normal for men. Studies show (Wisting et al. 2015 ) that $1 / 3$ of women and $1 / 6$ of men with type 1 diabetes mellitus manifest symptoms of eating disorders, and at the same time, reduce or skip insulin doses as a weight control strategy (diabulimia). Other forms of abnormal eating behaviours (including overeating, cleansing, laxative abuse and fasting for weight loss) are almost as common in men as in women (Mond et al. 2014).

Researchers emphasise that the presented epidemiological data concerning the incidence of eating disorders among men is underestimated. Men are less likely to seek help, and the diagnostic tools and specialist knowledge of ED diagnosis in this group are still imperfect. Many clinicians who diagnose eating disorders remain typical of women (Weltzin et al. 2005; Murray et al. 2016). Also, it turns out that standard tools for detecting ED in women curiously prove unsuitable for the diagnosis of men (Maine \& Bunnel 2010: 328). That is because, among other things, the statements and ques- 
tions they contain are not universal but relate directly to the lifestyle of women (e.g. “Are you trying to hide your breasts?”). Moreover, men lack considerable insight and knowledge about eating disorders. Thus in the course of diagnostic activities in men, specialists often look for the causes of existing problems in somatic diseases (e.g. gastric) or mental disorders (e.g. depressive disorders), other than eating disorders.

One of the critical, empirically confirmed trigger factors for developing eating disorders is dissatisfaction with one's own body. It turns out that $33 \%$ of Polish teenagers seeking to improve their image tried to lose weight "on their own", using various, drastic, dangerous to health and even life methods (Wojtyła 2011). One-quarter of the examined sample declared dissatisfaction with their body weight and a desire to reduce it; $50 \%$ reported excessive consumption, $40 \%$ experienced fear of obesity, $28 \%$ experienced food aversions, and 10\% induced vomiting. Reports from the US studies (Stice et al. 2017) confirm that striving for leanness, dissatisfaction with the body, dieting and unhealthy behaviours to control one's weight increase the risk of eating disorders. Interestingly, dissatisfaction with one's own body and its parameters appears regardless of the BMI value. Therefore, not so much the objective bodyweight as the subjective perception of it is the cause for provoking risky eating behaviours (e.g. restrictive diet) and dangerous compensation practices (e.g. stimulating vomiting, using laxatives without medical indications, taking para pharmaceuticals for "fat-burning").

Although the same diagnostic criteria are used to diagnose ED regardless of the patient's sex, there are some differences in the clinical picture of eating disorders and their determinants in men and women. Men diagnosed with ED are often labelled "effeminate" and perceive themselves as such (Maine \& Bunnel 2010). This kind of stigma is associated with more significant psychopathology, longer disease duration and stronger self-stigma (Murray et al. 2016).

Men suffering from eating disorders are more likely to be overweight than women before developing symptoms of the disorder, but the aim of their eating- and body-related activities is not to reduce the overall weight but to achieve the right body proportions (Pope et al. 2000a; Bąk 2008; Striegel-Moore et al. 2009). On the other hand, women focus more on the corporeality aspects related to adipose tissue (e.g. breasts, buttocks, belly) and their connection to fertility and cultural and biological significance (Bąk 2008, cf. Murray et al. 2016; Griffiths \& Yager 2019).

There are also differences in compensatory behaviours to regulate body weight and adjust the proportion of body weight according to gender. These are primarily intensive exercise and fasting in men, while in women, vomiting and abuse of laxatives and diuretics (Valente et al. 2017). However, according to Bunell (2010), clinicians downplay persistent physical exercise as a potentially compensatory activity in men because of physical activity and caring about muscular fitness in our society are considered appropriate and healthy. This situation indicates that the image of satisfaction with one's body does not stem directly from biological sex but gender roles connected with those mentioned above, stereotyping the male and female body (Bąk 2008: 171). Therefore, the attitude to one's own body results from the influence of socio-cultural standards created by popular culture and the media, which play a significant role in shaping the view of what the "ideal" male body should look like. In Western societies, there 
are significant differences between female and male attractiveness patterns: the female body should be slim while the male body should be low in fat but muscular and V-shaped (Pope et al. 2000a; Popek et al. 2011). Such an image, like the idea of a woman's beauty, can become both a point of reference in assessing one's physicality and attractiveness and a motivation to change the shape and proportions of one's body (Sharp et al. 1994; Hobza et al. 2007). Obsessive engagement in one's appearance, including the muscle structure, body weight, and applying various diets and measures to support building muscle tissue (e.g. anabolic steroids), may predispose men to develop muscle dysmorphia (Czepczor \& Brytek-Matera 2017). It often coincides with the devastating compulsive physical exercise called anorexia athletica (Morgan et al. 2008). A study showed that nearly $90 \%$ of teenage boys exercise for weight control (Eisenberg et al. 2012).

Sexual orientation plays a vital role in developing symptoms of ED in the male population. Cella et al. (2010) report that homosexual orientation is associated with increased body dissatisfaction and abnormal eating habits in men, especially those who claim they are not in a romantic relationship. At the same time, it has been shown that a sense of connection to the gay community reduces the likelihood of eating disorders (Waldron et al. 2009). Moreover, studies on sexual minorities in a sample of 2733 men (Murray et al. 2018) revealed a positive correlation between social media use and dissatisfaction with the body, symptoms of eating disorders, and the use or intent to use anabolic steroids. It has been documented (like in the case of women) that there are strong links between the use of image-oriented social networking sites (e.g. Instagram) and dissatisfaction with one's muscles, and symptoms of eating disorders. Nicholas Ray (2007) also emphasised that young homosexual and bisexual men were much more likely to fast, vomit, take laxatives and dietary preparations for weight control than their heterosexual peers. The research revealed that homosexual and bisexual men are much more likely to have full-blown bulimia nervosa and subclinical forms of any eating disorders.

On the other hand, Feldman and Meyer (2007) proved that $15 \%$ of homosexual and bisexual men and $4.6 \%$ of heterosexual men demonstrated full-blown or less-manifested eating disorders at some point in their lives. Also, transsexual persons were much more likely to report eating disorders in the year preceding the study (Diemer et al. 2015). This data contradicts the results of studies on bi- and homosexual women, as there are no statistically significant differences in the incidence of eating disorders in their population (Ray 2007). Although eating disorders are more common in men who identify themselves as homosexual or bisexual, most men with eating disorders are heterosexual (Strother et al. 2012).

One needs to note sexual abuse and psychoactive substance abuse among factors triggering eating disorder symptoms in the male population. As far as sexual abuse is concerned, the data is most likely underrepresented - about $30 \%$ of men suffering from ED (Connors \& Morse 1993). Shame resulting from such experiences and stigmatisation or fear of stigmatisation makes men reluctant to reveal their problems. Prior studies have also shown that men with eating disorders simultaneously struggle with disorders involving psychoactive substance abuse; then again, those presenting 
substance dependence symptoms often develop abnormal eating behaviours (Dunn et al. 2002). It appears that about $24 \%$ of people with a diagnosis of bulimia nervosa struggle with alcohol abuse or alcohol addiction (Costin 2007), and about $57 \%$ of men with eating disorders show signs of substance abuse, compared to only $28 \%$ of women (American Psychiatric Association 2006). Unfortunately, due to the tendency for men to have ED underdiagnosed, many are only treated for substance abuse, while food and body problems are neglected in their treatment (Costin 2007).

\section{DISCUSSION AND CONCLUSIONS}

As mentioned, a key mechanism within CSMM is prioritising everyday diversity in masculinities concerning the broader social, cultural and economic context. The added value to men's health research of incorporating the psychosocial explanation is to look at the psychosocial effects of positions in hierarchies (class, gender, ethnic) simultaneously. The impact of masculinities may be seen with class and ethnicity. Besides, it is to theorise some men's 'negative health behaviours' as a form of agency to overcome other types of inequalities which may also account for the relative obduracy of negative health behaviours among some men.

Although eating disorders are statistically more common in the female population, their quantity increases among men, and there are differences in clinical image, symptoms and co-existing gender-specific ED pathology (Valente et al. 2017). The essential features of eating disorders in men include:

1. greater (self-) stigmatisation than in the case of women, resulting from showing eating disorder symptoms;

2. longer diagnostics (than in the case of women) resulting in correct diagnosis and thus the implementation of appropriate forms of assistance;

3. an increasing percentage of ED in men - athletes, with anxiety personality, obese in childhood or non-heteronormative;

4. high probability of co-existing dysmorphic disorders and substance addiction in men with ED;

5. extreme care for the appearance of body parts, such as the abdomen, the thorax, the arms, the hands, and increased physical activity to create corporeality.

The introduction of gender issues into health care has been primarily concerned with the cultural determinants of women's physical health and well-being and had a feminist basis. A greater interest in masculine research dates back to the mid-1990s when the general interest in men's functioning was followed by research on their health. It is a paradox that in androcentric medicine, a reflection on and empirical verification of health determinants in men appeared so late. Despite the involvement of international committees in this issue (e.g. World Health Organization), it still seems that the problem of socio-cultural determinants of health in the male population is treated marginally, thus remaining largely unrecognised. 
In Poland, despite hundreds of publications showing differences in citizens' health situation considering their sex, the issue of gender specificity of health problems has been rarely addressed and, if so, mainly in studies on women, including those published by feminist organisations. The gender-specific context of men's health - apart from sexuality - is generally absent from the Polish literature.

It seems that singling out separate gender-specific criteria for ED diagnosis could facilitate timely diagnosis and accelerate effective planning and implementation of appropriate interventions. The introduction of gender issues into health care has been primarily concerned with the cultural determinants of women's physical health and well-being and had a feminist basis. The use of gender-sensitive clinical practices and the development of healthcare programmes or facilities specifically designed for men is a growing trend and an essential need in the healthcare sector (Jarrett 2007). Indeed, when considering men's health, it is crucial to take their age into account. Much of the research on health habits, risk behaviours, dietary practices etc., is conducted in a student environment (Snow 2008), yet the meaning of masculinity and aspects of masculinity change over a lifetime. Therefore, it is not reasonable to generalise the conclusions of such studies to the entire male population, as it distorts the picture (e.g. needs, attitudes, tasks, social roles) of men and complicates the planning and implementation of prevention programmes addressed to men at different stages of the life cycle.

FUNDING: This research received no external funding.

CONFLICT OF INTEREST: The authors declare no conflict of interest.

\section{REFERENCES}

Babbie, Earl. 2012. The practice of social research. Belmont, CA: Wadsworth Publishing. Bąk, Daniel. 2008. “Zaburzenia odżywiania się u mężczyzn.” [Eating disorders in men] Psychiatria Polska 42(2): 167-178.

Beaumont, Pierre J. V. \& Gerald F.M. Russell, 1972. “The occurrence of the syndrome of anorexia nervosa in male subjects.” Psychological Medicine 2: 216-231.

Bednarowska, Zofia. 2015. „Desk research - wykorzystanie potencjału danych zastanych w prowadzeniu badań marketingowych i społecznych.” [Desk research - exploiting the potential of secondary data in market and social research] Marketing i Rynek 7: 18-26.

Bradley, Harriet. 2007. Gender. Cambridge: Polity Press. https://doi.org/ $10.1177 / 0959353514540226$

Brannon, Linda. 2002. Gender. Psychological Perspectives (7th ed). London: Routledge.

Cella, Stefania, Mara Iannaccone, \& Paolo Cotrufo. 2010. "Body dissatisfaction, abnormal eating behaviours and eating disorder attitude in homo- and heterosexuals." Eating and Weight Disorders 15(3): 180-185. https://doi.org/10.3275/6866

Cinciara, Dorota. 2015. „Płeć kulturowa jako determinanta zdrowia mężczyzn.” [Gender as a determinant of male health] Zdrowie Publiczne i Zarzadzanie 13(4): 347- 
359. https://doi.org/ 10.4467/20842627OZ.15.036.5463

Connors, Mary E. \& Wayne Morse. 1993. "Sexual abuse and eating disorders: A review.” International Journal of Eating Disorders 13: 1-11. https://doi.org/10.1002/1098108X

Connell, Raewyn. W. 1995. Masculinities. Cambridge: Polity Press. https://doi.org/ 10.1177/000169939603900309

Connell, Raewyn. 2002. Gender. Cambridge: Polity Press.

Costin, Carolyn. 2007. The eating disorder sourcebook (3rd ed.). New York, NY: McGraw Hill.

Courtenay, Will. 2000. “Constructions of masculinity and their influence on men's well-being: a theory of gender and health." Social Science and Medicine 50(10): 1385-1401. https://doi.org/10.1016/s0277-9536(99)00390-1

Czepczor, Kamila \& Anna Brytek-Matera. 2017. Jedzenie pod wpływem emocji [Eating under emotions]. Warszawa: Wydawnictwo DIFIN.

Davidson Karina, Kimberlee J. Trudeau, Erica van Roosmalen, Miriam Stewart, \& Susan Kirkland. 2006. "Perspective: Gender as a health determinant and implications for health education.” Health Education and Behavior 33(6): 731-743. https://doi. org/ 10.1177/109019810 6288043

Doyal, Lesley. 2001. “Sex, gender and health: The need for a new Approach.” British Medical Journal 323(7320): 1061-1063. https://doi.org/10.1136/bmj.323.7320.1061

Diemer, Elizabeth, Julia D. Grant, Melissa A. Munn-Chernoff, David A. Patterson, \& Alexis E. Duncan. 2015. "Gender Identity, Sexual Orientation, and Eating-Related Pathology in a National Sample of College Students." Journal of Adolescent Health 57(2): 144-149. https://doi.org/10.1016/j.jadohealth.2015.03.003

Dunn, Erin C., Mary E. Larimer, \& Clayton Neighbors. 2002. "Alcohol and drug-related negative consequences in college students with bulimia nervosa and binge eating disorder.” International Journal of Eating Disorders 32(2): 171-178. https:// doi.org/10.1002/eat.10075

Eisenberg, Daniel, Nicole Speer, \& Justin B. Hunt. 2012. "Attitudes and beliefs about treatment among college students with untreated mental health problems.” Psychiatric Services 63(7): 711-713. https://doi.org/10.1176/appi.ps.201100250

Feldman Mathew B. \& Ilan H. Meyer. 2007. "Eating disorders in diverse lesbian, gay, and bisexual populations." International Journal of Eating Disorders 40: 218-226. https://doi.org/ 10.1002/eat.20360

Frąckowiak-Sochańska, Monika. 2011. „Zdrowie psychiczne kobiet i mężczyzn. Płeć społeczno-kulturowa a kategorie ‘zdrowia psychicznego' i chorób psychicznych.'” [Mental health for women and men. Socio-cultural gender and the categories of 'mental health' and 'mental illness'] Nowiny Lekarskie 80(5): 394-406.

Frąckowiak-Sochańska, Monika. 2014. „Płeć społeczno-kulturowa i zdrowie psychiczne w perspektywie refleksyjnej nowoczesności.” [Gender and mental health in the context of reflexive modernity] Kultura i Społeczeństwo 1: 39-60.

Griffiths, Scott \& Zali Yager, 2019. “Gender, Embodiment, and Eating Disorders.” Journal of Adolescent Health 64(4): 425-426. https://doi.org/10.1016/j.jadohealth.2019.01.016 
Hobza, Cody L., Karen E. Walker, Oksana Yakushko, \& James L. Peugh, 2007. "What about men? Social comparison and the effects of media images on body and self-esteem.” Psychology of Men \& Masculinity 8(3): 161-172. DOI: 10.1037/15249220.8.3.161

Hudson, James I., Eva Hiripi, Harrison G. Jr, Pope, \& R.C. Kessler, 2007. “The prevalence and correlates of eating disorders in the National Comorbidity Survey Replication.” Biological Psychiatry 61(3): 348-358. https://doi.org/10.1016/j.biopsych.2006.03.040

Józefik, Barbara. 1999. Anoreksja i bulimia psychiczna. Rozumienie i leczenie zaburzeń odżywiania się. [Anorexia and bulimia nervosa. Understanding and treating eating disorders] Kraków: Wydawnictwo Uniwersytetu Jagiellońskiego.

Keski-Rahkonen, Anna, Hans W. Hoek, Ezra S. Susser, Milla S. Linna, Elina Sihvola, Anu Raevuori, Cynthia M. Bulik, Jaakko Kaprio, \& Aila Rissanen. 2007. “Epidemiology and course of anorexia nervosa in the community." American Journal of Psychiatry 164(8): 1259-1265. https://doi.org/10.1176/appi.ajp.2007.06081388

Kluczyńska, Urszula. 2010. „Męskość i zdrowie. Analiza sposobu prezentacji wybranych problemów zdrowotnych w czasopiśmie dla mężczyzn Men’s Heath.” [Masculinity and health. An analysis of how selected health problems are presented in Men's Health magazine]. in Kobiety i mężczyźni (z) kolorowych czasopism [Women and men (from) coloured magazines], edited by A. Łysak \& E. Zierkiewicz. Wrocław: Oficyna Wydawnicza ATUT - Wrocławskie Wydawnictwo Oświatowe. https://doi.org/10.34616/22.19.231

Kluczyńska, Urszula. 2011. „Czy zdrowie ma płeć? Problematyka zdrowia kobiet w czasopismach dla mężczyzn.” [Does health have gender? Women's health problems in men's magazines] Nowiny Lekarskie 80(5): 334-343.

Krenn, Heidelinde. 2003. “Eßstörungen bei Männern: Charakteristika desVerlaufs von Anorexia nervosa und Bulimia nervosa bei Männern im Vergleich zu einer weiblichen Stichprobe.” Retrieved August 4, 2020 (http://archiv.ub.unimarburg. de/diss/z2004/0101/pdf/dhk.pdf).

Królikowska, Sabina. 2011. „Rola stereotypów płci w kształtowaniu postaw kobiet i mężczyzn wobec zdrowia.” [The role of gender stereotypes in shaping attitudes of women and men to health] Nowiny Lekarskie 80(5): 387-393.

Lavender, Jason M., Tiffany Brown, \&_Stuart B. Murray. 2017. “Men, Muscles, and Eating Disorders: An Overview of Traditional and Muscularity-Oriented Disordered Eating.” Current Psychiatry Reports 19(6): 32._https://doi.org/10.1007/s11920017-0787-5

Maine, Margo \& Bunnel Douglas. 2010. „Zaburzenia odżywiania się u mężczyzn.” [Eating disorders in men] Pp. 3-18 in Leczenie zaburzeń odżywiania. Pomiędzy nauka a praktyka [Treatment of eating disorders. Between science and practice], edited by M. Maine, B. McGilley, D. Bunnel. Amsterdam, London, Heidelberg: Elsevier.

Mathewson, Sara H. 2009. Man is the remedy of man: constructions of masculinity and health-related behaviour among young men in Dakar Senegal. London: London School of Economics and Political Science, Development Studies Institute.

Mond, Jonathan, Deborah Mitchison, \& Phillipa Hay. 2014. "Prevalence and impli- 
cations of eating disordered behavior in men.” in Current findings on males with eating disorders, edited by L. Cohn \& R. Lemberg. Philadelphia, PA: Routledge. https://doi.org/10.1186/1471-2458-14-943

Morgan, John, Samantha Scholtz, Hubert Lacey, \& Gerard Conway. 2008. "The prevalence of eating disorders in women with facial hirsutism: an epidemiological cohort study." International Journal of Eating Disorders 41(5): 427-431. https:// doi.org/10.1002/eat.20527

Murray, Stuart B., Scott Griffiths, \& Jonathan Mond. 2016. “Evolving eating disorder psychopathology: conceptualising muscularity-oriented disordered eating.” The British Journal of Psychiatry 208(5): 414-5. https://doi.org/10.1192/bjp. bp. 115.168427

Murray, Stuart, Jason Nagata, Scott Griffiths, Jerel Calzo, Tiffany Brown, Deborah Mitchison, Aaron Blashillh, \& Jonathan Mond. 2017. "The enigma of male eating disorders: A critical review and synthesis." Clinical Psychology Review 57: 1-11. https://doi.org/10.1016/ j.cpr.2017. 08.001

Murray, Stuart B., Devin Rand-Giovannetti, Scott Griffiths, \& Jason Nagata. 2018. “Locating the mechanisms of therapeutic agency in family-based treatment of adolescent anorexia nervosa: A pilot study of clinician/researcher perspectives." Eating Disorders: the Journal of Treatment \& Prevention 26: 477-486. https://doi. org/10.1080/10640266.2018.1481306

Pope, Harison, Amanda Gruber, Barbara Mangweth, Benjamin Bureau, Christine deCol, Roland Jouvent, \& James Hudson. 2000a. "Body image perception among men in three countries”. American Journal of Psychiatry 157(8): 1297-1301. https://doi. org/10.1176/appi.ajp157.8.1297

Pope, Harison, Katharine Phillips, \& Roberto Olivardia. 2000b. The Adonis complex: The secret crisis of male body obsession. New York: Free Press.

Popek, Lidia, Katarzyna Bażyńska, Monika Misiec, Barbara Remberk, \& Monika Turno. 2011. „Rozumienie zaburzeń odżywiania się u adolescentów płci męskiej w ujęciu psychodynamicznym, systemowym i behawioralno-poznawczym.” [Understanding of eating disorders in male adolescents in psychodynamic, systemic and behavioral-cognitive approach] Psychoterapia 4(159); 5-15.

Ray, Nicholas. 2007. Lesbian, Gay, Bisexual and Transgender Youth. An Epidemic of Homelessness. New York: National Gay and Lesbian Task Force Policy Institute and the National Coalition for the Homeless.

Renzetti, Claire \& Daniel Curran. 2003. Women, men and society. Boston: Allyn and Bacon.

Robertson, Steve. 2007. Understanding men and health: masculinities, identity and well-being. New York: Open University Press. ISBN: 9780335221578

Saetnan, Ann R., Nelly Oudshoorn, \& Małgorzata Kirejczyk. 2000. Bodies of technology. Women's involvement in reproductive medicine. Columbus, $\mathrm{OH}$ : Ohio State University Press.

Sharp, Cliff W., Stella Clark, Howard Blackwood, \& Colin Shapiro. 1994. “Clinical presentation of anorexia nervosa in males: 24 new cases.” International Journal of Eating Disorders 15: 125-134. https://doi.org/10.1002/1098-108X 
Sinem Akgül, Devrim Akdemir, Mahmut Kara, Orhan Derman, Füsun Çuhadaroğlu Çetin \& Nuray Kanbur. 2016. "The understanding of risk factors for eating disorders in male adolescents”. Internationl Journal of Adolescent Medicine and Health, 28(1):97-105. https://doi.org/10.1515/ijamh-2014-0078.

Smink, Frederique, Daphne van Hoeken, \& Hans Hoek. 2012. "Epidemiology of eating disorders: Incidence, prevalence and mortality rates." Current Psychiatry Reports 14(4): 406-414. https://doi.org/10.1007/s11920-012-0282-y

Snow, Rachel. 2008. "Sex, gender, and vulnerability.” Global Public Health 3(1): 5874. https://doi.org/10.1080/17441690801902619

Stice, Eric \& Cara Bohon. 2012. "Eating Disorders.” in Child and Adolescent Psychopathology, edited by T. Beauchaine \& S. Linshaw. New York: Wiley.

Stice Eric-, Jeff M. Gau, Paul Rohde, \& Heather Shaw. 2017. "Risk factors that predict future onset of each DSM-5 eating disorder: Predictive specificity in high-risk adolescent females." Journal of Abnormal Psychology 126(1): 38-51. https://doi. org/10.1037/abn0000219

Striegel-Moore, Ruth, Fracine Rosselli, \& Helena Kraemer. 2009. “Gender difference in the prevalence of eating disorder symptoms." International Journal of Eating Disorders 42: 471-474. https://doi: 10.1002/eat.20625

Strother, Eric, Raymond Lemberg, Stevie Stanford, \& Dayton Turberville. 2012. "Eating Disorders in Men: Underdiagnosed, Undertreated, and Misunderstood.” Eating disorders 20(5): 346-55. https://doi.org/10.1080/10640266.2012.715512

Urban, Ewa, Maria Piotrowicz, Dorota Cinciara, Małgorzata Gajewska, \& Katarzyna Lewtak. 2014. “The attention to the issues of women's and men's health - quantitative and qualitative analysis of publications in selected on-line bibliographic databases." Pp. 258-292 in There is no health without public health research, edited by D. Cinciara. Warszawa: Narodowy Instytut Zdrowia Publicznego - Państwowy Zakład Higieny.

Valente, Stefano, Giulia Di Girolamo, Martina Forlani, Anna Biondini, Paolo Scudellari, Diana De Ronchi, \& Anna R. Atti. 2017. "Sex-specific issues in eating disorders: a clinical and psychopathological investigation." Eating and Weight DisordersStudies on Anorexia, Bulimia and Obesity 22: 707-715. https://doi.org/10.1007/ s40519-017-0432-7

Vlassoff, Carol. 2007. "Gender differences in determinants and consequences of health and illness." Journal of Health, Population and Nutrition 25(1): 46-61. ISSN: 20721315

Waldron, Jennifer J., Tamar Z. Semerjian, \& Kerrie Kauer. 2009. “Doing ‘Drag’: Applying Queer-Feminist Theory to the Body Image and Eating Disorders across Sexual Orientation and Gender Identity.” Pp.63-81 in The Hidden Faces of Eating Disorders, edited by J. J. Ree \& K. A. Beals. Sewickley, PA: American Alliance for Health Physical.

Weltzin, Theodore, Nicolette Weisensel, Margaret Burnett, Christine Klitz, \& Pamela Bean. 2005. “Eating disorders in men: update." The Journal of Men's Health \& Gender 2(2): 186-193. https://doi.org/10.1016/j.jmhg.2005.04.008

Westerberg, Dyanne \& Margot Waitz. 2013. “Binge-eating disorder”. Osteopathic Family 
Physician, 5(6): 230-233. ISSN: 1877-573X

Wisting, Line, Lasse Bang \& Øywind Rø. 2015. "Adolescents with T1D-The impact of gender, age, and health-related functioning on eating disorder psychopathology." PLoS ONE 10(11): e0141386. https://doi.org/10.1371/journal.pone.0141386

WHO. 2011. Madrid statement. Mainstreaming gender equity in health: the need to move foreward. Copenhagen: WHO Regional Office for Europe. Retrieved August 2, 2020 (https://www.who.int/whosis/whostat/WHS2011_addendum.pdf?ua=1).

Woynarowska, Barbara. 2012. Edukacja zdrowotna. Podręcznik akademicki. [Health education. Academic handbook] Warszawa: PWN.

Zhao, Yafu \& William Encinosa. 2011. "An Update on Hospitalisations for Eating Disorders, 1999 to 2009.” Healthcare Cost and Utilization Project (HCUP) Statistical Briefs. Retrieved 30 May, 2020 (https://www.hcup-us.ahrq.gov/reports/statbriefs/sb120.pdf). 